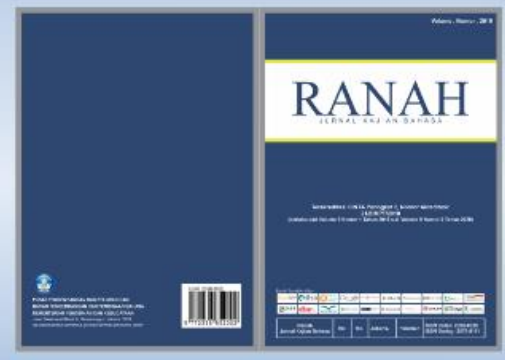

Ranah: Jurnal Kajian Bahasa

ojs.badanbahasa.kemdikbud.go.id/jurnal/index.php/jurnal_ranah

p-ISSN: 2338-8528

e-ISSN: $2579-8111$

\title{
PENERJEMAHAN FRASA VERBAL DARI BAHASA INGGRIS KE BAHASA INDONESIA
}

Translating English Phrasal Verbs into Indonesian

\author{
Engliana $^{a}$ dan Ira Miranti ${ }^{b}$ \\ a,bUniversitas Indraprasta PGRI \\ engliana.seok@gmail.com,ade_miranti@yahoo.com
}

\author{
Naskah Diterima Tanggal 26 Juni 2018-Direvisi Akhir Tanggal 23 Maret 2020_Disetujui Tanggal 13 Mei 2020 \\ doi: https://doi.org/10.26499/rnh/v9i1.862
}

\begin{abstract}
Abstrak
Penelitian ini menganalisis penerjemahan frasa verbal dari bahasa Inggris ke bahasa Indonesia. Tujuan dari penelitian ini adalah mengidentifikasi pemahaman penerjemah melalui kesepadanan makna frasa verbal bahasa Indonesia. Usaha identifikasi ini bermanfaat untuk mengenali bahwa pemahaman makna kombinasi frasa verbal bahasa sumber dan konteks penggunaan frasa verbal dalam kalimat dapat diserap dengan baik oleh penerjemah sehingga dapat menghasilkan terjemahan yang tepat. Penelitian ini didasarkan pada pendekatan kualitatif, yaitu menggunakan metode kajian isi. Teknik analisis data menggunakan kategori atau pemisahan hasil terjemahan berdasarkan jenis frasa verbal bahasa sumber, kemudian kriteria kesepadanan makna diterapkan pada hasil terjemahan. Hasil analisis menunjukkan bahwa para responden masih menghadapi kesulitan menerjemahkan frasa verbal bahasa Inggris ke bahasa Indonesia karena mereka masih terpaku pada struktur frasa verbal bahasa sumber dan kurang memahami kaidah struktur bahasa sumber (linguistic barrier). Didapati juga metacognitive barrier, yaitu kurang latar belakang pengetahuan yang diperoleh dari pengalaman sehingga mempengaruhi kemampuan membangun strategi dan memengaruhi pengambilan putusan.
\end{abstract}

Kata-kata kunci: penerjemahan, frasa verbal, kesepadanan

\begin{abstract}
This research analyzes the translation of English phrasal verbs into Indonesian. The goal of this research is to identify the translators' understanding by means of equivalent translation of the phrasal verbs in Indonesian. Such goal is valuable since it helps us to see how the translators were able to comprehend meanings in context. The translation results also enable us to recognize the translators' understandings of phrasal verbs of source language and their meanings in target language. This is a qualitative research which employs content analysis method. The data analysis technique is categorizing, or separation of the translation results based on the source language's phrasal verbs type prior to applying meaning equivalence principles to the translations. The results of the analysis show that the respondents still face difficulties in translating English phrasal verbs into Indonesian because they are fixated on the verbal structures of source language and lack of understanding of the rules of the source language structure (linguistic barrier). Metacognitive barrier plays a role in the translation process due to lack of background knowledge gained from experience, thus affecting the ability to build strategies and influence decision-making.
\end{abstract}

Keywords: translation, phrasal verb, equivalence

How to Cite: Engliana dan Ira Miranti. (2020). Penerjemahan Frasa Verbal dari Bahasa Inggris ke Bahasa Indonesia. Ranah: Jurnal Kajian Bahasa, 9(1), 56-71. doi: https://doi.org/10.26499/rnh/v9i1.862 


\section{PENDAHULUAN}

Bahasa Inggris dan Indonesia memiliki sistem struktur masing-masing, namun kedua sistem ini memiliki perbedaan karena bahasa Indonesia bukan termasuk kelompok Bahasa IndoEropa, seperti halnya bahasa Inggris. Oleh karena perbedaan sistem dasar ini, kegiatan menerjemahkan bahasa Inggris ke bahasa Indonesia dan sebaliknya menjadi kompleks. Sang penerjemah harus memikirkan kesepadanan leksikon dan penyesuaian tata bahasa. Dalam penelitian ini, kesepadanan penerjemahan leksikon berpusat pada salah satu leksikon yang sering menjadi masalah dalam penerjemahan, yaitu frasa verbal.

Hakikat utama frasa verbal menjadi pusat analisis penelitian ini adalah fungsi frasa verbal dapat berperan sebagai unsur predikat dalam kalimat (Chaer, 2006: 317). Oleh karena itu, verba dasar menjadi komponen utama dalam frasa. Predikat menjadi "bagian kalimat yang menandai apa yang dikatakan oleh pembicara tentang subjek" (Badan Pengembangan dan Pembinaan Bahasa, 2019a). Fungsi ini memiliki peran untuk mengatur makna subjek dan objek kalimat. Steiner dalam Hansen-Schirra \& Gutermuth (2015: 56) berpendapat frasa verbal juga termasuk tata bahasa metafora sebab tata bahasa ini "menyuarakan" ide atau makna yang sama dengan memakai kategori frasa yang berbeda, misalnya seperti klausa bertingkat, klausa, frasa, alih-alih memilih menggunakan kosakata sederhana. Dengan memahami fungsi dan peran predikat ini, penerjemah dapat mencari kesepadanan leksikon dalam menerjemahkan frasa verbal agar hasil terjemahan menjadi sepadan, sederhana, tepat, jelas, dan langsung pada inti pesan (Newmark, 1988).

Susilo (2018) menemukan bahwa penerjemahan frasa verbal berbasis kategori kala bahasa Inggris ke bahasa Indonesia lewat buku ajar sosiolinguistik memerlukan penyesuaian dua hal, yaitu bentuk dan makna. Penyesuaian segi bentuk merujuk pada penyesuaian kelas kata dan tata bahasa, sedangkan penyesuaian segi makna terdapat sekitar $46 \%$ frasa verbal yang agak tepat diterjemahkan. Hasil ini menunjukkan bahwa perlu ketelitian dan pemahaman struktur bahasa sumber (BSu) serta pemilihan kata bahasa sasaran (BSa). Penyesuaian sistem ortografis dan fonologis juga dapat diambil sebagai alternatif strategi untuk "mempertahankan makna konsep secara utuh yang terkandung dalam istilah suatu bahasa yang maknanya tidak terungkap oleh bahasa lain" (Nur, 2017: 134). Terkadang, frasa verbal bahasa Inggris dapat mengandung makna leksikal lainnya dari makna kata verba intinya sendiri. Penerjemahan gaya bahasa patut mempertimbangkan keindahan tanpa melupakan keakuratan makna di sebuah novel klasik tahun 1928 dari bahasa Inggris ke bahasa Indonesia. Sang penerjemah menggunakan sembilan teknik penerjemahan, yaitu 
padanan lazim, kreasi diskursif, reduksi, peminjaman, literal, adisi, modulasi, eksplisitasi, dan adaptasi (Pratiwi et al. 2018: 208). Sementara itu, Putra (2019) memilih telaah penerjemahan frasa bahasa Inggris ke bahasa Indonesia lewat buku biografi politik yang berfokus pada ideologi dan teknik penerjemahan. Ideologi penerjemahan yang dikaji adalah penerjemahan kata dan kalimat dengan kandungan unsur budaya, yang banyak menggunakan pergeseran kelas kata untuk ideologi asing dan teknik peminjaman murni untuk ideologi lokal. Perpaduan dua teknik penerjemahan ini disebabkan oleh ideologi sang penerjemah, yaitu ketika si penerjemah berada dalam posisi harus memilih untuk buku terjemahan ini bisa dipahami oleh para pembaca berbahasa Indonesia atau mempertahankan struktur dan budaya dari si penulis buku BSu.

Hasil penelitian itu telah memberikan gambaran dan keterkaitan dengan penelitian ini. Masing-masing penelitian tersebut memiliki kancah tersendiri. Susilo fokus pada bentuk kata dan makna penerjemahan frasa verbal dari sudut pandang jenis kala bahasa Inggris dengan satu buku ajar yang menggunakan bahasa akademis dan diterjemahkan oleh seorang penerjemah berpengalaman sebagai sumber datanya. Sementara itu, Putra fokus pada ideologi penerjemahan dan teknik penerjemahan yang mengikuti ideologi tersebut. Penelitian Pratiwi et al. (2018) mengarah pada keakuratan terjemahan gaya bahasa pada karya sastra.

Permasalahan dalam penelitian sebelumnya ada bagian kecil yang belum sempat dikaji, misalnya seperti susunan gramatikal frasa verbal, khususnya jenis frasa verbal yang disandingkan dengan preposisi objek (prepositional object) karena susunan ini jarang diperhatikan dan penggunaan sumber data yang langsung dari lapangan. Selain itu, penelitian lainnya banyak meninjau satu hasil BSa saja karena produk terjemahan itu telah dicetak dalam bentuk buku yang sudah disunting (satu kali atau lebih) oleh editor bahasa/ pengelola/penyelia percetakan buku tersebut. Apabila penelitian dilaksanakan mulai dari tahap awal, yaitu ketika penerjemah/mahasiswa/i menghadapi naskah BSu, penelitian itu dapat melihat ragam terjemahan awal yang dihasilkan untuk dapat memahami jika penerjemah/mahasiswa/i tersebut mengerti benar makna frasa verbal BSu. Kancah penelitian ini adalah membahas hasil penerjemahan verba frasa bahasa Inggris ke dalam bahasa Indonesia dengan mengambil data langsung dari lapangan dan komponen khusus pada frasa verbal yang disandingkan dengan preposisi objek. Rumusan masalah penelitian ini ialah apakah frasa verbal bahasa Inggris dengan susunan verba + preposisi dan frasa verbal + 
preposisi objek dapat diterjemahkan dengan tepat dengan konteks bahasa yang minimal, yaitu dalam satu kalimat?

\section{LANDASAN TEORI}

Nida memandang penerjemahan sebagai suatu kajian ilmu ilmiah, yakni kajian pada struktur-struktur kebahasaan, analisis semantis, dan teori komunikasi. Selanjutnya, Nida (2003) berijtihad bahwasanya penerjemahan itu lebih pada tingkat fungsi, yakni terdiri dari keterampilan, ilmu, dan taktik. Nida juga mendebat bahwa kegiatan penerjemahan adalah sesuatu yang mustahil karena bahasa-bahasa di dunia memiliki karakteristik sendiri sehingga kesepadanan makna bersifat relatif. Oleh karena itu, teori linguistik berlaku dalam proses penerjemahan. Teori penerjemahan diperoleh dari proses penerjemahan, lalu dikembangkan sesuai dengan perbedaan struktur bahasa sumber dan sasaran, serta hasil budaya dari masingmasing bahasa tersebut.

Nida dan Taber (1982) menggambarkan tiga tahap proses penerjemahan, yaitu (a) Tahap Analisis: terjadi ketika penerjemah menganalisis teks BSu dalam hubungan gramatikal yang ada dan (b) Tahap Transfer: terjadi pemahaman makna kata dan rangkaian kata-kata. Hasil tahap ini ialah makna bahasa sumber ke dalam bahasa sasaran. Setelah itu, (c) Tahap Restrukturisasi, yakni makna tersebut ditulis kembali ke dalam bahasa sasaran, ada dalam bahasa sasaran. Larson (1998: 4) menggambarkan proses terjemahan lebih sederhana lagi. Proses ini terdiri atas tiga tahap, yaitu (a) mempelajari leksikon, tata bahasa, situasi komunikasi, dan konteks budaya $\mathrm{BSu}$; (b) analisis hasil tahap pertama untuk mencari maknanya dalam BSa; dan (c) mengekspresikan ulang makna yang telah ditemukan itu dalam BSa.

Perbedaan dua proses penerjemahan ini terletak pada tahap pencarian makna. Proses pencarian makna terjadi pada tahap transfer menurut konsep Nida dan Taber, sedangkan proses pencarian makna menjadi langkah awal menurut konsep Larson. Sekilas dua konsep ini membedakan proses pencarian makna, tetapi pada saat penerjemahan dimulai ada kalanya sang penerjemah harus menganalisis hubungan gramatikal bahasa terlebih dahulu sebelum mengolah maknanya. Ada kala saat sang penerjemah dapat langsung mencari makna terlebih dahulu, kemudian menganalisis tatanan gramatikal sehingga kesepadanan dapat dicapai. 


\section{Kesepadanan makna dalam penerjemahan}

Berikutnya adalah lima konsep kesepadanan menurut Baker (2011: 11) yang terdiri atas (1) kesepadanan pada tataran kata (equivalence at word-level), yakni tingkat kesepadanan pada bagian permukaan kata dan/atau kalimat, yaitu tata struktural dan komponen makna; (2) kesepadanan di atas tataran kata (equivalence above word level), yakni tingkat kesepadanan pada tataran frasa; (3) kesepadanan tata bahasa (grammatical equivalence), yakni tingkat kesepadanan pada keterikatan tata bahasa BSu dan BSa dalam segi morfologi dan sintaksis; (4) kesepadanan tekstual (textual equivalence), yakni tingkat kesepadanan berbasis pada jenis informasi yang disampaikan, tema teks, kohesi teks antara $\mathrm{BSu}$ dan $\mathrm{BSa}$; (5) kesepadanan pragmatis (pragmatic equivalence)-tingkat kesepadanan fungsi teks dalam situasi komunikasi tertentu antara BSu dan Bsa.

Khusus penelitian ini, istilah kriteria kesepadanan yang paling memenuhi tujuan penelitian adalah konsep kesepadanan di atas tataran kata karena bahasan mengacu pada frasa verbal dalam bahasa Inggris yang apabila disandingkan dengan preposisi dapat mengubah makna verba dasarnya. Perubahan makna semantis ini membuat penerjemah harus mencari padanan kata bukan dari kata dasar verbanya, yaitu dari makna kamus semata, tetapi mereka harus mencari padanan frasa verbal itu lewat sumber lain seperti kamus metafora atau idiom, lalu membandingkannya konteks kalimat tempat frasa verbal itu dipakai

\section{Kaidah struktur frasa verbal dalam bahasa Inggris}

Frasa verbal dalam bahasa Inggris memiliki dua kombinasi, yaitu verba dengan preposisi ('give up', berasal dari verba give dan preposisi up yang artinya 'menyerah', 'carry on', berasal dari verba carry dan preposisi on yang artinya 'meneruskan') yang kehadiran preposisi ini mengubah makna verba. Preposisi paling umum dipakai adalah preposisi penanda tempat atau lokasi, seperti: in, out, on, off, over, up, down, dan through.

Kedua, kombinasi frasa verbal dengan preposisi objek (keep up with - , look down on') yang tidak mengubah makna frasa verbal dasarnya yang dengan kata lain dapat dijabarkan ciri strukturnya adalah kombinasi frasa verbal dan preposisi objek yang dipakai setelah verba meskipun bukan menjadi bagian dari verba tersebut. Akan tetapi, preposisi ini diperlukan sebelum kata benda atau objek yang akan muncul setelah verba itu (Leech, 1989; Murphy, 2012). 
Kedua jenis frasa verbal ini dapat menjadi verba transitif (diikuti oleh nomina)- kecuali struktur kombinasi dengan preposisi objek-atau intransitif (tidak diikuti nomina) dan ragam dalam macamnya. Seluruh frasa verbal selalu memungkinkan dapat diterjemahkan secara harafiah ke dalam Bahasa Indonesia. Akan tetapi, dalam perihal mencari makna yang sepadan, seorang penerjemah harus meninjau kembali frasa verbal BSu dari situasi atau konteks kalimat karena terjemahan yang dihasilkan akan memiliki makna yang berbeda walaupun menggunakan verba yang sama.

\section{Kaidah struktur frasa verbal dalam bahasa Indonesia}

Frasa verbal adalah bagian dari kalimat yang berupa verba dengan atau tanpa objek dan/atau keterangan dalam kaidah struktur frasa dan yang berfungsi sebagai predikat. (Badan Pengembangan dan Pembinaan Bahasa, 2019b). Contohnya, sebuah kata dasar verba 'makan' (base atau root) ditinjau dari segi morfologis hanya dengan menambah afiks 'makan' + -an 'makanan' yang dari segi semantisnya pada kata tersebut adalah 'segala apa yang boleh dimakan--seperti penganan, lauk-pauk, dan kue' (Badan Pengembangan dan Pembinaan Bahasa, 2018).

Dalam teori tata bahasa Indonesia, ada beberapa pengertian tentang frasa verbal. Pertama, "frasa verba[1] ialah satuan bahasa yang terbentuk dari dua kata atau lebih dengan verba sebagai intinya tetapi bentuk ini tidak merupakan klausa" (Alwi et al., 2000: 157). Menurut tata bahasa Indonesia, istilah frasa diartikan sebagai gabungan dua buah kata atau lebih yang merupakan satu kesatuan, dan menjadi salah satu unsur atau fungsi kalimat, yaitu subjek, predikat, objek, atau keterangan (Chaer, 2006: 301). Contohnya, frasa gunung tinggi adalah hasil gabungan antara dua buah kata gunung (nomina) dan tinggi (adjektiva) yang memiliki artinya masing-masing sebelum digabung menjadi satu frasa. Contoh lain tentang frasa verbal dalam kalimat: [1] Keuangannya sudah membaik; [2] Helikopter itu akan mendarat. Verba inti [1] dan [2] adalah membaik dan mendarat. Namun, ada kata lain yang mendampingi verba intinya. Kata pendamping ini bersifat tegar atau tetap sehingga tidak dapat dipindahkan secara bebas ke posisi lain (Alwi et al., 2000: 157). Sementara itu, frasa verbal pada kalimat [1] adalah sudah membaik dan pada kalimat [2] akan mendarat. Selain itu, bila ditinjau dari segi fungsinya, frasa verbal menduduki fungsi predikat.

Namun, ada juga frasa verbal yang menduduki fungsi lain sebagai subjek, predikat, objek, dan keterangan (Chaer, 2006). Contoh: (a) Frasa verbal sebagai predikat terdapat dalam kalimat Pemerintah akan mengesahkan peraturan pajak baru. Frasa verbal akan 
mengesahkan menjadi predikat dari kalimat tersebut, tetapi diikuti oleh unsur lain, yaitu peraturan pajak baru; (b) Frasa verbal sebagai subjek terdapat dalam kalimat Olahraga teratur membuat orang menjadi sehat. Frasa verbal olahraga teratur menjadi subjek kalimat; (c) Frasa verbal sebagai objek dalam kalimat Adik mencoba tidur lagi. Frasa verbal yang menjadi objek kalimat ialah tidur lagi; (d) Frasa verbal sebagai pelengkap terdapat dalam kalimat Menantunya merasa tidak bersalah. Frasa verbalnya ialah tidak bersalah yang berfungsi sebagai pelengkap dari predikat merasa. Tanpa frasa verbal tidak bersalah maka predikat tersebut tidak lengkap.

\section{METODE PENELITIAN}

Metode penelitian ini adalah kajian isi dengan pendekatan kualitatif. Penelitian ini memenuhi karakteristik penelitian kualitatif karena memiliki ciri latar alamiah, manusia sebagai alat atau instrumen, penerapan penelaahan dokumen, analisis data induktif, data yang dikumpulkan dalam bentuk deskriptif, yaitu hasil terjemahan dalam bentuk tulisan, dan desain penelitian yang bersifat sementara karena adanya kenyataan jamak di lapangan yang tidak dapat diramalkan sebelumnya sehingga peneliti harus melakukan penyesuaian (Moleong, 2017: 8-13). Teknik penelitian menjabarkan (a) responden penelitian sebagai instrumen; (b) sumber tertulis; dan (c) catatan lapangan sebagai berikut.

Responden yang diminta untuk menerjemahkan frasa kerja dalam artikel ini adalah mahasiswa bukan jurusan bahasa Inggris. Mereka diminta dan bersedia untuk berpartisipasi dalam proses pengambilan data dengan berperan sebagai responden. Pada saat diminta kesediaan berpartisipasi, mereka sedang mengambil kursus bahasa Inggris di suatu lembaga bahasa milik perguruan tinggi swasta di Jakarta. Usia mereka bervariasi, yakni mulai dari usia 19--20 tahun. Akan tetapi, dua orang penerjemah lepas ditemui di hari dan pada waktu yang terpisah dengan para mahasiswa tersebut. Rentang usia penerjemah lepas ini antara 25-40 tahun. Hasil terjemahan keduanya tidak dibedakan dengan hasil terjemahan dari mahasiswa karena dianggap kedua kelompok ini tidak masuk dalam kategori penerjemah profesional.

Penelitian berlangsung di kampus tempat tujuh mahasiswa/i sedang mengambil kursus bahasa Inggris. Kampus ini menjadi pilihan utama mereka karena tempat tersebut paling dekat sehingga pengambilan data bisa dilaksanakan setelah mereka selesai kursus. Waktu yang dipilih tidak mengganggu jam perkuliahan mereka. Tempat yang sama juga disepakati bersama dengan dua responden lainnya yang bekerja sebagai penerjemah lepas. Namun, 
untuk kedua penerjemah lepas ini, waktu yang dipilih tidak sama dengan waktu yang dipilih oleh para mahasiswa dan mahasiswi.

Sumber data untuk penelitian ini adalah tes penerjemahan. Tes penerjemahan ini terdiri atas kumpulan beberapa frasa verbal terpilih oleh peneliti. Kriteria pemilihan frasa verbal dalam tes ini adalah sumber buku les bahasa Inggris yang sedang dipakai oleh para mahasiswa dan mahasiswi responden. Frasa verbal yang dikumpulkan sesuai dengan verba frasa bahasa Inggris, yaitu susunan verba + preposisi dan frasa verbal + preposisi objek

Pelaksanaan pengumpulan data untuk artikel ini, penulis menggunakan tes terjemahan yang berisi sejumlah frasa verbal berbahasa Inggris yang dipilih dari buku ajar bahasa Inggris dengan maksud untuk mencari frasa verbal yang sering digunakan dalam buku ajar berbahasa Inggris sehingga para responden diharap merasa akrab dengan frasa verbal tersebut. Hasil terjemahan dikumpulkan dalam satu kolom, tetapi bila didapati ada hasil terjemahan yang sama dari dua responden atau lebih, hasil terjemahan tersebut akan dianggap sebagai satu jenis hasil terjemahan saja. Hasil terjemahan akan dibandingkan dengan soal yang diberikan. Perbandingan ini akan ditinjau dari segi (a) komponen kata BSaBSu dan (b) makna yang mengikat dari BSa-BSu tersebut. Hasil terjemahan para responden akan dianalisis dari sudut pandang tata bahasa Inggris dalam hal ini khususnya adalah tata bahasa frasa verbal dalam bahasa Inggris. Setelah melihat dari segi tata bahasa Inggris, hasil terjemahan dalam bahasa Indonesia akan dianalisis. Sudut pandang tata bahasa Indonesia akan digunakan untuk menelaah hasil terjemahan tersebut

\section{PEMBAHASAN}

Berikut adalah hasil penerjemahan dari tujuh orang mahasiswa/i, beserta dua orang penerjemah lepas yang telah bekerja dibidangnya masing-masing. Kesembilan orang ini memiliki latar belakang pendidikan bukan jurusan bahasa Inggris dan sedang memperdalam kecakapan mereka di kelas Conversation Class for Pre-Intermediate. Verba dalam bahasa Inggris yang disajikan pada para responden ialah

1. $\quad \boldsymbol{d r y}$ (off, out, up),

2. $\quad$ get (through, into, off, in + with, back), dan

3. drop (in, behind, off, out, in + the bucket).

Frasa verbal bahasa Inggris dengan kata dry pada Tabel 1, get pada Tabel 2, dan drop pada Tabel 3 dalam konteks penggunaan dalam kalimat dan makna masing-masing frasa verbal menurut konteks. Khusus verba drop, disisipkan satu kalimat idiom drop in the bucket. Ragam frasa verbal BSu diberi nomor satu sampai dengan 13 (tiga belas) di dalam 
kolom frasa verbal. Kolom berikutnya adalah kolom kalimat yang terdiri atas pemakaian frasa verbal BSu dalam satu kalimat, sehingga para responden dapat memberi terjemahan sesuai dengan konteks frasa verbal BSu dalam kalimat tersebut. Kolom terakhir adalah kolom hasil terjemahan. Kolom ini diisi dengan sejumlah hasil terjemahan, yakni BSa yang diberi penomoran dengan alfabet (a), (b), (c) dan seterusnya, sesuai dengan banyaknya hasil terjemahan tersebut. Jumlah maksimal untuk BSa adalah sembilan ragam terjemahan karena disesuaikan dengan jumlah responden dalam penelitian ini. Dalam tes, mereka hanya boleh menerjemahkan satu macam saja untuk menghindari keraguan dalam pilihan kata atau frasa BSa.

Teknik kode data menggunakan dua elemen dari data tersebut, yaitu tabel dan nomor frasa verbal dalam tabelnya. Contohnya, frasa verbal dry off ada di Tabel 1 dan nomor satu pada kolom frasa verbal, maka kode data frasa verbal dry off adalah (1-2) yang artinya frasa verbal ini terdapat pada tabel pertama, yakni Tabel 1 dan kalimat pertama dalam tabel tersebut.

Tabel 1

Hasil terjemahan frasa verbal $d r y$

\begin{tabular}{|c|c|c|}
\hline Frasa Verbal & Kalimat & Hasil Terjemahan \\
\hline 1. dry off & Clean the cut and dry it off carefully & $\begin{array}{l}\text { (a) keringkan*, } \\
\text { (b) dikeringkan, } \\
\text { (c) mengeringkan }\end{array}$ \\
\hline 2. dry out & Put your coat on the radiator to dry out & $\begin{array}{l}\text { (a) dikeringkan* atau kering*, } \\
\text { (b) dari basah menjadi kering, } \\
\text { (c) mengering, } \\
\text { (d) mengeringkan }\end{array}$ \\
\hline 3. dry up & $\begin{array}{l}\text { Our research project is cancelled when the } \\
\text { money dries up }\end{array}$ & $\begin{array}{l}\text { (a) habis*, } \\
\text { (b) tidak cukup, } \\
\text { (c) basah, } \\
\text { (d) kekurangan, } \\
\text { (e) berkurang, } \\
\text { (f) dikurangi, } \\
\text { (g) krisis, } \\
\text { (h) mengering }\end{array}$ \\
\hline
\end{tabular}

* kata yang digarisbawahi merupakan terjemahan yang benar dari verba frasa bahasa Inggris dalam kolom kalimat.

Tabel 2

Hasil terjemahan frasa verbal get

\begin{tabular}{lll}
\hline Frasa Verbal & Kalimat & Hasil Terjemahan \\
\hline & & (a) lulus*, \\
& (b) keluar kelas, \\
1. get through & (c) melewati, \\
& (d) mengambil, \\
& (e) menjalani, \\
& (f) mengerjakan, \\
& (g) menaruh \\
\hline \multirow{5}{*}{ get into } & (a) memasuki*, \\
& (b) masuk, \\
& (c) mencapai, \\
& (d) mengikuti, \\
& (e) masuk ke, \\
& (f) diterima, \\
& (g) dapat masuk
\end{tabular}




\begin{tabular}{|c|c|c|c|}
\hline 3. get off & The bus got off finally & $\begin{array}{l}\text { (a) } \\
\text { (b) } \\
\text { (c) } \\
\text { (d) } \\
\text { (e) } \\
\text { (f) } \\
\text { (g) } \\
\text { (h) } \\
\text { (i) } \\
\text { (j) }\end{array}$ & $\begin{array}{l}\text { berangkat*, } \\
\text { meninggalkan, } \\
\text { telah berangkat, } \\
\text { berhenti, } \\
\text { mogok, } \\
\text { telah mencapai, } \\
\text { pergi, } \\
\text { sampai, } \\
\text { kosong, } \\
\text { datang }\end{array}$ \\
\hline 4. get in with & Mark tries to get in with someone & $\begin{array}{l}\text { (a) } \\
\text { (b) } \\
\text { (c) } \\
\text { (d) } \\
\text { (e) } \\
\text { (f) } \\
\text { (g) } \\
\text { (h) } \\
\text { (i) }\end{array}$ & $\begin{array}{l}\text { bergaul akrab dengan*, } \\
\text { bertemu, } \\
\text { memperoleh, } \\
\text { pergi, } \\
\text { masuk bersama dengan, } \\
\text { masuk (dengan), } \\
\text { meminang, } \\
\text { pergi bersama, } \\
\text { berteman }\end{array}$ \\
\hline 5. get back & Get back in line! & $\begin{array}{l}\text { (a) } \\
\text { (b) } \\
\text { (c) }\end{array}$ & $\begin{array}{l}\text { kembali*, } \\
\text { masuk kembali, } \\
\text { ambil }\end{array}$ \\
\hline
\end{tabular}

* kata yang digarisbawahi merupakan terjemahan yang benar dari verba frasa bahasa Inggris dalam kolom kalimat.

Tabel 3

Hasil terjemahan frasa verbal drop

\begin{tabular}{|c|c|c|}
\hline Frasa Verbal & Kalimat & Hasil Terjemahan \\
\hline 1. drop in & Please drop in to see me & $\begin{array}{l}\text { (a) mampir/singgah*, } \\
\text { (b) turun, } \\
\text { (c) memasukkan, } \\
\text { (d) masuk, } \\
\text { (e) mengantar, } \\
\text { (f) berkunjung }\end{array}$ \\
\hline 2. drop behind & Receipts dropped behind last year & $\begin{array}{l}\text { (a) berkurang*, } \\
\text { (b) menurun, } \\
\text { (c) masuk sebelum, } \\
\text { (d) diberikan terlambat, } \\
\text { (e) menurun dari, } \\
\text { (f) penurunan diberikan }\end{array}$ \\
\hline 3. drop off & The leaves are dropping off & $\begin{array}{l}\text { (a) berguguran* } \\
\text { (b) berjatuhan, } \\
\text { (c) menurunkan, } \\
\text { (d) jatuh ke bawah, } \\
\text { (e) berhenti, } \\
\text { (f) gugur }\end{array}$ \\
\hline 4. drop out of & He is about to drop out of the race. & $\begin{array}{l}\text { (a) keluar*, } \\
\text { (b) dikeluarkan (dari), } \\
\text { (c) tidak ikut, } \\
\text { (d) menurunkan } \\
\end{array}$ \\
\hline 5. drop in the bucket & $\begin{array}{c}\text { His contribution was a drop in the } \\
\text { bucket. }\end{array}$ & $\begin{array}{l}\text { (a) sedikit (sekali)*, } \\
\text { (b) dimasukkan dalam keranjang, } \\
\text { (c) masuk ke kantong, } \\
\text { (d) hanya sampai situ saja, } \\
\text { (e) menyumbang uang, } \\
\text { (f) tidak berguna, } \\
\text { (g) digunakan, } \\
\text { (h) sedikit berguna }\end{array}$ \\
\hline
\end{tabular}

* kata yang digarisbawahi merupakan terjemahan yang benar dari verba frasa bahasa Inggris dalam kolom kalimat.

Bagian ini membagi bahasan menurut dua jenis frasa verbal yang menjadi fokus penelitian ini, yakni pembahasan terjemahan frasa verbal dengan kombinasi verba + preposisi dan kombinasi frasa verbal + preposisi objek. Dalam perihal tingkat kesepadanan, 
fokus bahasan ini pada tingkat kesepadanan di atas tataran kata (equivalence above word level).

\section{Menerjemahkan Verba + Preposisi}

Pola penambahan adverbia pada verba dapat ditemukan dalam verba frasa dari kata dasar verba get, yaitu dry off (1-1), dry out (1-2), dries up (1-3); kemudian dari kata dasar verba get, yaitu get through (2-1), get into (2-2), get off (2-3), get back (2-5), dan dari kata dasar verba drop, seperti drop in (3-1), drop behind (3-2), dan drop off (3-3).

Hal pertama yang harus diperhatikan ialah melihat bentuk verba yang dipakai dalam kalimat. Contohnya pada kalimat (1-3), verba dasar dry merupakan intinya. Lalu verba $d r y$ ini digabungkan dengan kata up yang menjadi dry up.

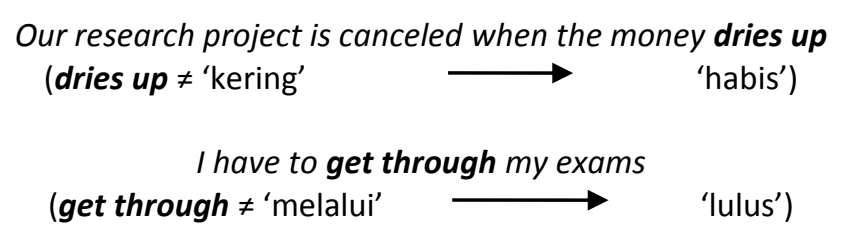

Dalam Longman Dictionary of Contemporary English (Pearson, 2014), frasa verbal dry up ini memiliki tiga macam makna dengan konteks kalimat yang berbeda pula:

Makna ke-1 : if a supply of something dries up, there is no more of it (='habis')

Makna ke-2 : if a river or lakes dries up, the water in it disappers (= 'kering')

Makna ke-3 : to dry plates, dishes etc that have been washed (= 'mengeringkan')

Setelah mengetahui makna tersebut, barulah si penerjemah memilih mana yang paling tepat untuk konteks kalimat. Dari ketiga makna itu, makna kedua dan ketiga jelas tidak cocok dalam konteks kalimat Our research project is cancelled when the money dries up karena mengacu kepada makna harfiah dari verba dry. Verba dry berubah maknanya dalam konteks kalimat money dries up.

Dengan adanya preposisi pada verba, maka bentukan ini tidak mengubah makna dasar verba yang dipasangkan sehingga mempermudahkah penerjemah untuk dapat menebak makna dalam konteks kalimat tersebut. Akan tetapi, perlu berhati-hati untuk segi morfologinya, yaitu penggunaan imbuhan pada verba Indonesia karena akan mempengaruhi segi semantisnya. Contohnya dapat dilihat pada kalimat lengkap (1-1) dan (1-2) berikut ini. 
Frasa verbal dry off (1-1) dan dry out (1-2) memiliki arti verba yang sama dalam bahasa Indonesia (hal ini sudah memperhitungkan konteks kalimat), yaitu 'kering'. Dari segi morfologinya dapat dilihat seperti ini.

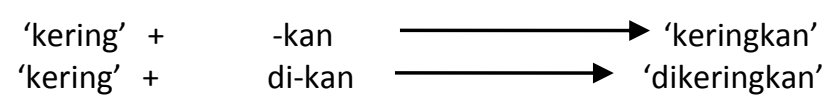

Terjemahannya dalam bahasa Indonesia dapat dilihat dari beragam macam sehingga pilihan kata dan imbuhan sangat berperan penting dalam kalimat seperti berikut ini; ada tiga macam imbuhan yang dapat dipakai oleh penerjemah dalam kalimat tersebut, yaitu 'kering' (tanpa imbuhan), 'dikeringkan' (di-kan), dan 'keringkan' (-kan).

(a) Letakkan mantelmu di atas radiator itu supaya kering atau

(b) Letakkan mantelmu di atas radiator itu untuk dikeringkan atau

(c) Keringkan mantelmu di atas radiator itu

Dalam (a), 'supaya kering' menunjukkan kegiatan akibat atau hasil dari perbuatan meletakkan mantelnya di atas radiator; yang mengeringkan mantelnya adalah radiator, bukan orang. Pada (b) kata 'dikeringkan' merujuk kepada bentuk kalimat pasif dari 'mengeringkan'. Jadi sekali lagi, yang mengeringkan adalah alat. Sementara itu, pada kalimat (c), verba 'keringkan' berstatus transitif karena diikuti oleh nomina mantelmu dan merujuk pada makna kata tugas, yaitu 'meletakkan mantel' yang artinya melakukan perbuatan yang dikatakan oleh kata dasar 'kering'.

Hasil terjemahan para responden banyak yang tidak sepadan dengan makna yang ada dalam BSu. Dari 13 macam kombinasi frasa verbal bahasa Inggris, terdapat satu bagian BSu yang tepat dalam BSa, yakni kombinasi verba frasa dengan preposisi dry off dan dry out. Namun, hasil ini tidak semata-mata menunjukkan bahwa kombinasi verba frasa yang demikian mempermudah para responden untuk menerjemahkan arti keduanya dengan BSa akurat. Pernyataan ini terbukti dengan ada kombinasi verba frasa yang sama tidak dapat diterjemahkan ke dalam BSa yang tepat. Meskipun frasa verbal sudah diberi posisi dalam kalimat sehingga tercipta konteks terbatas dalam kalimat tersebut, hasil terjemahan akurat masih sulit dihasilkan oleh para responden. Akhirnya, dapat dipastikan bahwa para responden gagal menempatkan verba inti dalam konteks kalimat terbatas tersebut; mereka dianggap masih bingung dengan kombinasi verba frasa yang disajikan. 
Dari segi semantisnya, penerjemah dianjurkan untuk mempertimbangkan kembali maknanya karena pemakaian afiks dalam bahasa Indonesia akan mengubah makna kata dan

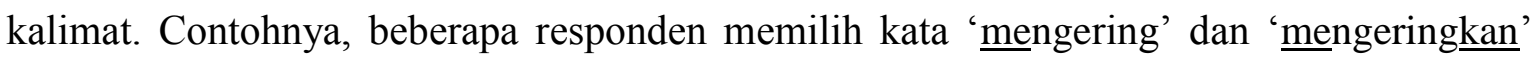
untuk verba frasa dry out. Pilihan kedua kata ini tidak tepat karena imbuhan me- dan mekan langsung mengubah makna, yaitu apabila dilihat kembali apa/siapa yang menjadi pelaku dan apa/siapa yang 'membuat menjadi kering'.

\section{Menerjemahkan Frasa Verbal + Preposisi Objek dan Idiom dengan Frasa Verbal}

Dengan adanya frasa verbal yang digabungkan dengan prepositional object menjadikan makna verba itu berubah dan apabila dipasangkan dengan preposisi makna verba itu cenderung tetap, hal ini membuat penerjemah harus berhati-hati dalam menerjemahkan. Lalu, bagaimana menerjemahkan frasa verbal dengan susunan frasa verbal bersanding dengan preposisi objek seperti dalam frasa get in with (2-4)?

Perlakuan yang sama dengan yang di atas berlaku untuk menerjemahkannya. Tapi ada hal yang perlu diperhatikan adalah fungsi preposisi dalam VF dengan frasa verbal + preposisi objek ini. Fungsi preposisi adalah untuk menghubungkan puak benda (noun phrase) dengan verba frasanya (Leech, 1989: 357-358). Contoh dalam kalimat (2-4) adalah sebagai berikut: Mark tries to get in with someone ( = 'befriend'). Maka, verba inti dari (2-4) adalah get, yang disematkan preposisi in lalu diikuti dengan preposisi objek with yang fungsinya mengubah makna verba frasa get in dan menghubungkan puak benda someone dalam kalimat tersebut. Hasil terjemahan yang paling tepat dari responden adalah (i), yaitu 'berteman' yang merupakan BSa paling mewakili makna sesungguhnya. Dua responden lain menerjemahkan frasa 2-4 ini dengan makna yang merujuk pada arah, yaitu menerjemahkan dengan kata 'masuk.' Hal ini dapat disebabkan oleh dua responden tersebut mengambil acuan informasi dari frasa verbal sebelumnya, yaitu 'get into' (2-2) dengan makna 'masuk.'

Selain itu, keunikan frasa verbal dengan preposisi objek ini seperti kombinasi dari kata dasar verba drop, yaitu drop out of (3-4) yang frasa verba drop out disemat dengan preposisi off dan drop in the bucket (3-5) yang membentuk idiom karena mengubah makna dasar frasa verbalnya karena tidak bisa memisah rangkaian frasa ini dari puak benda the bucket. Pertama, frasa verba idiom dalam kalimat (3-5) ini terdiri atas frasa verbal drop in dan puak benda the bucket yang apabila diartikan secara harfiah menurut strukturnya ini, kemungkinan terjemahan idiom ini akan mengandung verba 'mampir', 'singgah' atau 'berkunjung'. Kemudian, puak benda the bucket mungkin akan diterjemahkan menjadi 
'ember' atau 'ember itu'-dengan pertimbangan partikel the dalam frasa. Namun, apabila verba bahasa Indonesia 'mampir', 'singgah', atau 'berkunjung' tersebut disematkan dengan 'ember itu', bentukan frasa yang tidak ada maknanya. Kesadaran akan tidak ada kaitan antara dua frasa ini hendaknya membuat para responden mulai menentukan pilihan lain untuk menerjemahkan idiom tersebut, yaitu mulai mencari kata yang mirip dalam kalimat (3-1) His contribution was a drop in the bucket. Kalimat ini terdapat penggunaan frasa verbal yang sama, yaitu drop in. Jadi, kata verba 'masuk' memikili frekuensi tertinggi kata terjemahan yang dipakai dalam kalimat (3-1) dan (3-5). Kekerapan yang tinggi ini menjadi bukti bahwa para responden betul-betul melihat kalimat (3-1) sebagai sumber referensi mereka dalam memilih kata dalam BSa. Akan tetapi, strategi ini tidak berhasil karena frasa verba berada pada tingkat kesepadanan di atas tataran kata, termasuk dalam penggunaannya pada ekspresi idiomatik. Para responden harus berpikir keras apabila verba BSa 'masuk' dari drop in terhubung dengan subjek his contribution dan puak benda the bucket. Terbukti dari hasil terjemahan (e) sedikit berguna agak dekat dengan terjemahan akurat (a) sedikit (sekali), namun tambahan adverbia 'berguna' membuat makna BSu menjadi kurang tepat.

Terakhir, frasa (3-4) drop out of diterjemahkan dengan baik oleh para responden, kecuali satu terjemahan yang gagal mendekati makna sepadan, yaitu terjemahan (d) 'menurunkan'. Terjemahan (c) 'tidak ikut' sebenarnya tidak akurat dari segi makna karena berbeda artinya dengan 'keluar'-subjek telah mengikuti pertandingan-karena terjemahan (c) mengandung makna bahwa si subjek tidak pernah ikut dalam pertandingan sejak dari awal, mungkin menjadi penonton saja. Hasil ini menjadi bukti bahwa sebagian besar para responden sudah paham konsep makna frasa verbal drop out ini sehingga kesalahan penerjemahan bisa terhindari. Salah satu kemungkinan kesukesesan ini adalah para responden biasa terpapar dengan jenis frasa verbal ini. Penelitan lebih lanjut tentang paparan ini bisa dikaji dalam penelitian lainnya.

Bahasan dari dua fokus penelitian ini telah menentukan bahwa frasa verbal bahasa Inggris memiliki bentukan makna dan konsep yang tingkat kesepadanannya ada di atas tataran kata (equivalence above word level) karena kombinasinya membuat makna kata verba dasarnya berubah sedemikian rupa. Terjemahan frasa verbal ini tidak semata-mata juga dapat diterjemahkan ke tingkat padanan di atas tataran kata juga dalam bahasa Indonesia karena terjemahannya malah menjadi verba yang biasa (equivalence at word level), tanpa perubahan makna. Pernyataan ini berlaku dalam konteks penelitian ini semata karena luas 
cakupan yang dikaji belum sepenuhnya mewakili penerjemahan frasa verbal bahasa Inggris ke bahasa Indonesia secara menyeluruh.

\section{PENUTUP}

Kombinasi sederhana verba + preposisi banyak gagal diterjemahkan oleh para responden, sedangkan dua kombinasi frasa verbal + preposisi objek juga kurang akurat penerjemahannya. Frasa verbal dalam idiom tidak bisa diterjemahkan dengan baik karena makna yang diberikan meleset dari makna kalimat. Terdapat beberapa faktor dalam kegagalan ini, yaitu pertama, para responden kurang paham atau tidak paham penggunaan imbuhan dalam bahasa Indonesia sehingga penggunaan imbuhan yang tidak tepat akhirnya mengubah makna dari pilihan kata dasar verba bahasa Indonesia yang sudah tepat. Kedua, para responden terpaku pada pola yang sama dari kombinasi verba lainnya, akibatnya mereka menggunakan pilihan kata yang serupa dan menggunakan strategi penerjemahan yang sama dengan pola struktur frasa verba sebelumnya; hal ini terlihat jelas ketika harus menerjemahkan idiom dengan pola frasa verba yang mirip dengan frasa verba di kalimat awal. Apabila dipersingkat, faktor penyebab pertama adalah kegagalan linguistik (linguistic barrier)-gramatikal dan leksikal dua bahasa (BSu dan BSa) dan kegagalan metakognitif (metacognitive barrier)-terhubung dengan latar belakang pengetahuan (knowledge) penerjemah tentang suatu tema termasuk pengalamannya dengan membaca kata-kata tertentu dan kemampuan regulasi (regulation) untuk pemecahan masalah dan pengambilan putusan dalam proses penerjemahan. Dua hal ini sebaiknya bisa berpadu serasi bila dalam keadaan seimbang agar penerjemah dapat menghasilkan terjemahan alamiah, akurat, dan jelas.

Penerjemah dianjurkan untuk cermat dalam menggunakan imbuhan dalam bahasa Indonesia karena akan mempengaruhi kalimat dari segi sintaktis dan semantis. Hal ini lebih baik bagi para penerjemah untuk memiliki alat-alat penerjemahan yang cukup dan mutakhir untuk mendukung kelancaran proses penerjemahan. Dalam perihal kajiannya, frasa verbal ini sangat luas karena tidak hanya ditinjau dari segi gabungan kata dengan preposisi dan preposisi objek saja. Apabila memungkinkan, frasa verbal ini dapat dianalisis dari segi morfologis dan sintaktisnya. Dari segi semantisnya dapat mengacu kepada ungkapan atau idiom karena ada idiom bahasa Inggris yang menggunakan frasa verba dalam struktur sintaksisnya. Kajian segi pragmatis juga dapat dianalisis untuk melihat kemampuan penerjemah untuk memahami konteks budaya dan sosial dalam teks dua budaya yang berbeda. 


\section{DAFTAR PUSTAKA}

Alwi, H., Dardjowidjojo, S., Lapoliwa, H., \& Moeliono, A. M. (2000). Tata Bahasa Baku Bahasa Indonesia. Jakarta: Balai Pustaka.

Badan Pengembangan dan Pembinaan Bahasa. (2018). Kamus Besar Bahasa Indonesia Daring. https://kbbi.kemdikbud.go.id/entri/makanan

Badan Pengembangan dan Pembinaan Bahasa. (2019a). Kamus Besar Bahasa Indonesia. https://kbbi.kemdikbud.go.id/entri/predikat

Badan Pengembangan dan Pembinaan Bahasa. (2019b). Kamus Besar Bahasa Indonesia. https://kbbi.kemdikbud.go.id/entri/frasa verbal

Baker, M. (2011). In Other Words: A Coursebook on Translation (2nd ed.). New York: Routledge. https://doi.org/10.4324/9780203832929

Chaer, A. (2006). Tata Bahasa Praktis Bahasa Indonesia (4th ed.). Jakarta: Rineka Cipta.

Hansen-Schirra, S., \& Gutermuth, S. (2015). Approaching Comprehensibility in Translation Studies. In K. Maksymski, S. Gutermuth, \& S. Hansen-Schirra (Eds.), Translation and Comprehensibility (pp. 53-76). Berlin: Frank \& Timme.

Larson, M. L. (1998). Meaning-Based Translation: A Guide to Cross Language Equivalence (2nd ed.). New York: University Press of America.

Leech, G. (1989). An A-Z of English Grammar and Usage. London: E. Arnold.

Moleong, L. (2017). Metodologi Penelitian Kualitatif (28th ed.). Bandung: Remaja Rosdakarya.

Murphy, R. (2012). English Grammar in Use. Cambridge: Cambridge University Press.

Newmark, P. (1988). A Textbook of Translation (12th ed.). New York: Prentice-Hall International. https://doi.org/10.1017/CBO9781107415324.004

Nida, E. A. (2003). Toward a Science of Translating. Leiden: E.J. Brill.

Nida, E. A., \& Taber, C. (1982). The Theory and Practice of Translation. Leiden: E.J. Brill.

Nur, M. (2017). Harmoni Bahasa dari Perspektif Penerjemahan dalam Kasus Pemadanan Istilah Teknis: Suatu Kajian Pustaka. Ranah: Jurnal Kajian Bahasa, 6(6), 119. https://doi.org/10.1177/0309133309346882

Pearson. (2014). Longman Dictionary of Contemporary English. $5^{\text {th }}$ Edition. https://www.ldoceonline.com/dictionary/dry-up

Pratiwi, N., Nababan, M., \& Djatmika, N. (2018). Keakuratan Terjemahan Gaya Bahasa pada Novel "Lady Chatterley's Lover". Ranah: Jurnal Kajian Bahasa, 7(2), 194-209. https://doi.org/10.26499/rnh.v7i2.634

Putra, P. P. (2019). Ideologi dan Teknik Penerjemahan Frasa pada Buku Biografi "Suharto (A Political Biography)" dari bahasa Inggris ke dalam bahasa Indonesia karya R.E. Elson (Studi Analisis Isi). Tsaqofah dan Tarikh: Jurnal Kebudayaan Dan Sejarah Islam, 4(1), 27. https://doi.org/10.29300/ttjksi.v4i1.2220

Susilo, D. (2018). Penerjemahan Frasa Verba Bahasa Inggris dalam Buku "Sociolinguistics: Goals, Approaches and Problems" karya Roger T. Bell ke dalam bahasa Indonesia pada buku "Sosiolinguistik: Sajian, Tujuan, Pendekatan dan Problem" oleh Abdul Syukur Ibrahim. JDPP: Jurnal Dimensi Pendidikan dan Pembelajaran, 6(1), 29-38. http://journal.umpo.ac.id/index.php/dimensi/index\%0D 